\title{
CORPORATE KNOWLEDGE MANAGEMENT: INTERDISCIPLINARY APPROACH
}

\author{
ANDREI KAPTEREV \\ Academy of labor and social relations, Moscow, Russia
}

\section{ABSTRACT}

Governing the professional and intellectual potential interdisciplinary field of scientific research and a systematic process of creating, using and developing the innovation technologies of transforming the individual knowledge and specialists' experience in such a way that would apply the knowledge and experience to the processes, services and products offered by an organization to reach its strategic goals. From the technological standpoint, governing the professional and intellectual potential represents modeling, forming, using and developing the corporate system of governing the professional and intellectual potential, including: (a) corporate model of external environment and internal business processes; (b) corporate information system; (c) corporate knowledge management system (KMS); and (d) corporate learning management system (LMS). Author considers structuring knowledge using this model rather valuable during the stage of forming the governance system of the professional and intellectual potential. Understanding, i.e., explicit definition of these factors, would allow for constant observation of the behavioral trends and for organizing the activity in a way conducive for influencing the favorable change of these factors. In addition, the presence of the critical management factor (CMF) system enables one to check the significance of any activity (i.e., any processes within a company) against these factors.

\section{JEL CLASSIFICATION \& KEYWORDS}

- D83 | 015 - Professional knowledge - Knowledge management - Corporate level n Intellectual capital — Professional space - Professional culture = Interdisciplinary approach

\section{INTRODUCTION}

Philosophical and economic study of the social dimensions of professional knowledge has been intensifying in the decades since 1970. Social controversies about the sciences and science based technologies as well as developments in philosophical naturalism and social epistemology combine to drive thinking in this area forward. Scholars in a number of cognate disciplines continue to investigate the myriad social relations within communities and between them and their social, economic, and institutional contexts. These investigations provide both source material for sociological analysis and challenges to conventional approaches to understanding professional knowledge.

\section{Background}

From the early days of science, scholars were interested in intellect as an attribute of an individual and a socialization condition. Thus, Socrates [1] identified education as a major characteristic of a cultured person; Francis Bacon [2] regarded intelligence as one of the three bases for dividing sciences into classes. The founder of sociology, Auguste Comte [3], who substantiated the notions of social statics and social dynamics, proposed a mechanism of social development based upon intellectual evolution of human consciousness. He considered science as the highest manifestation of intellectual evolution. Herbert Spencer [4] paid special attention to the analysis of the influence of collective activity on the social evolution. Emile Durkheim www.journals.cz/
[5] explained appearance of social phenomena with certain needs of the society contemporary to that epoch. Many scholars of corporate culture rely upon the concept of «social facts» that they introduced, i.e., ideas, norms, and values collectively developed by the people. Collectivity, according to E. Durkheim, is a major social factor. Max Weber's theory [6] entitled Understanding Sociology permitted to shift the accent in learning the social facts towards consciousness of a subject of social action and analysis of its motivational and value realm. Many problems of self-realization are viewed today through the prism of «purposeful-rational action», which is one of the four ideal types of social action described by Max Weber. The study of social action continued by Talcott Parsons [7] as part of the structural and functional analysis provided an opportunity to examine their situational nature. The issue of relationship between consciousness and action analyzed in the Marxist sociology as a dialectic interaction gave an impulse to the development of the action-based approach in the Russian human science research, including, among others, the psychological works of L. S. Vygodsky and A. N. Leontiev.

K. Mannheim [8], a prominent knowledge sociologist, formulated and substantiated the ideas of socio-cultural knowledge determination. Communication theories of Marshall McLuhan [9], John Naisbitt [10], Patricia Aburden [11], Alan Toffler [12], and Manuel Castells [13] determined the specifics of post-industrialism, which is observed in the increased influence of information and professional knowledge upon the development of the modern society. Karin Knorr Cetina [14] reviewed the social mechanisms of knowledge generation using the example of natural sciences, similarly to the natural selection in the biological evolution. French anthropologist Bruno Latour [15] and British sociologist Steve Woolgar demonstrated from the perspective of the social constructivism how nonsystematized knowledge is put in order. Annie Brooking [16] proposed a term «intellectual capital» (IC), and L. Edvinsson [17] and M. S. Malone analyzed its accumulation within an organization. Pierre Bourdier [18] regarded IC as a combination of cultural capital (in particular, its three major states: incorporated, objective and institutionalized) and social capital. He demonstrated how one form of capital is transformed into another one. Baruch Lev [19] proposed a technology for measuring and monitoring the IC growth. Karl-Erik Sveiby [20] identified 25 methods of measuring IC, which he grouped into four categories. I. Nonaka and $\mathrm{H}$. Takeuchi were pioneers in connecting the effectiveness of the Japanese companies with their ability to generate new knowledge and apply it for industrial production of products and technologies [21]. They provided an inside perspective of the Japanese companies towards the organizational aspects of new knowledge generation.

The Russian specialists also examine various aspects of intellectual capital in an organization. However, the literature lacks a unified sociological concept of governing the professional and intellectual potential.

\section{Basics}

In our works we brought to light the differences between some economic models: a) raw model; b) industrial model; 
CORPORATE KNOWLEDGE MANAGEMENT: INTERDISCIPLINARY APPROACH

\begin{tabular}{|c|c|c|c|c|c|}
\hline $\begin{array}{l}\text { Dominant } \\
\text { reservoir }\end{array}$ & $\begin{array}{l}\text { Dominant } \\
\text { resource }\end{array}$ & \begin{tabular}{|l|} 
Dominant \\
process
\end{tabular} & Result & Potential (result / resource) & $\mathrm{KPI}$ \\
\hline substance & natural & mining & minerals & $\mathrm{f}$ (mined minerals/ found out resources) & distance \\
\hline energy & material & making & produce & f (produce / resources) & time \\
\hline information & informative & distribution & information service & $f$ (available information / kept information) & speed \\
\hline knowledge & intellectual & employment & innovations & f (applied knowledge / available knowledge) & precipitation \\
\hline
\end{tabular}

c) information model; d) knowledge model. We considered the potential of these models as correlation of results and resources. Also we showed our opinion about key performance indicators (KPI) of each model (see table 1).

In our research [22] we fulfill the task of substantiating the information and communication approach to analyzing the intellectual and professional spaces through conducting interdisciplinary study of the professional environment of a modern organization. The conceptual frameworks of the intellectual space as a whole and governing the dynamics of the professional space at the corporate level were proposed during this research phase. The author examined a great variety of different approaches to governing professional development, each of which emphasizes a certain aspect - economic, psychological, sociological, and others. We consider all of the aforementioned methodologies important and valuable; however, an information and communication approach to analyzing professional space is proposed for the purposes of this research, which is based on the structural and functional approaches developed by the Russian scholars. The conceptual model of the intellectual space is built using these methodological guidelines.

The major characteristics of intellectual space include: (a) integrity; (b) communicativeness; (c) dynamics; (d) expansion of limits; and (e) increasing density.

Based upon the analysis of the intellectual space, the definition of "professional space" is created. The author uses this term to describe constantly changing fragment of social space that consists mainly of four key structural elements: (a) dynamics of professional activity objects, i.e., production, distribution and exchange of the resulting products; (b) dynamics of communication between the objects of professional activity, (c) dynamics of professional consciousness, i.e., changing attitude towards the modifications of the first two types inside and outside the organization; and (d) dynamics of professional culture, i.e., tangible professional memory.

It has been demonstrated that although professional and intellectual potential has informational nature, it is simultaneously characterized with such attributes as productivity, structure, and latency. These qualities make it unnecessary to limit personal knowledge to latent and public knowledge to tangible kind. The study justified differentiation of the professional and intellectual potential according to its systematization levels: (a) intuitive knowledge (associations, opinions, hypotheses); (b) conceptual knowledge (thesauri, frames, semantic networks); and (c) systematized knowledge (rules, theorems, laws). The issue of converting information into knowledge and vice versa is examined as a process of objectivation - desobjectivation of professional and intellectual potential. This process is informational in its nature, educational in its form, and subjective in its character. The author identified the following knowledge types at the corporate level: (a) deep; (b) strategic (ensuring success), and (c) innovation knowledge.

\section{Conclusion}

As a result, the author's definitions are formulated:

1. Governing the professional and intellectual potential interdisciplinary field of scientific research and a systematic process of creating, using and developing the innovation technologies of transforming the individual knowledge and specialists' experience in such a way that would apply the knowledge and experience to the processes, services and products offered by an organization to reach its strategic goals.

2. From the technological standpoint, governing the professional and intellectual potential represents modeling, forming, using and developing the corporate system of governing the professional and intellectual potential, including: (a) corporate model of external environment and internal business processes; (b) corporate information system; (c) corporate knowledge management system (KMS); and (d) corporate learning management system (LMS).

As we have demonstrated, the foreign methods of governing the professional and intellectual potential assume by default the presence of identified (and, usually, also formalized) business processes and view the company management as managing a system of interrelated business processes; this is reflected in the international standards for management quality. However, the Russian practice shows that clear understanding of which processes take place within an organization is not an attribute of many companies. Therefore, it is feasible to separate the independent types of professional knowledge, which is required for managing the professional and intellectual potential of a company: (a) knowledge about process - knowledge of the company structure, business processes and functions that take place, areas of responsibility, work rules; (b) knowledge about people, which add their competency, qualification, use of technology, and responsibility for the quality of work; (c) knowledge about systems; and (d) knowledge about goals.

The author further substantiated and examined the following functions of professional knowledge: (a) praxeological; (b) communicative; (c) cognitive; and (d) axiological.

The proposed approach to governing the professional and intellectual potential identifies several governing principles for professional and intellectual potential, its modeling, forming, use and development: paradigmatic, goal-oriented, balanced, normative, flexible, innovational, and reflexive.

Knowledge generation is not the ultimate self-purpose of the professional and intellectual potential governance projects; their strategy should be related to the business goals and desired results of organization's work. Forming the corporate knowledge management system (KMS) is defined as a permanent cyclical process consisting of four stages: (a) assessment of external trends; (b) selection of knowledge management strategy; (c) selection of software for knowledge management; and (d) achievement of real business results. 
We explained five basic management processes of the professional and intellectual potential: (a) creating professional knowledge, (b) systematization, (c) providing access, (d) organizing search, and (e) use. We also identified four types of technology, which ensure the functionality of the professional and intellectual potential governance decisions: semantic, team-working, visualization, scalability technologies. The spectrum of their application ranges from tactical to strategic use.

The major means supporting the governance of professional and intellectual potential include (a) data mining and text mining, which imply identifying meaningful regularities from the archival or input-output data; (b) document management systems - storage, archival, indexing, document markup and publication; (c) means of organizing collaborative work - Internet, teamwork technologies, synchronized and nonsynchronized conferences; (d) corporate knowledge portals; and (e) decision support systems - expert systems supporting discussion groups, etc.

The following functional structure of a corporate information portal is proposed: (a) portal's search system; (b) news section for publishing the latest events and programs related to a certain topic; (c) forum for discussing the topical themes and documents related to various aspects; (d) annual calendar of subject areas reflecting all the major professional events; (e) idea and brainstorming section for initiating the creation and implementation of various projects and initiatives in a subject area as well as for proposing new forms of expanding professional communication; (f) partnership and collaboration - section introducing the currents and proposed programs and allowing for partner search or proposing own cooperation forms; and (g) expert council - section providing consulting assistance for organizing various projects in this sector of professional culture.

Based upon the research conducted, the conceptual model of governing the professional and intellectual potential of an organization was constructed and substantiated. We used the methodology of the key performance indicators (KPI) in order to build the goal structure [tree] in our model. The proposed system of governing the professional and intellectual potential includes previously examined processes, whose content is represented as a management object and could be put into the matrix of the professional and intellectual potential governance factors, which is represented by the Table 2 .

We now have an opportunity to represent all of the factors form this matrix in a form of a figure reflecting the model of governing the professional and intellectual potential of an organization. The use of this model is a subject of the subsequent studies.

We consider structuring knowledge using this model rather valuable during the stage of forming the governance system of the professional and intellectual potential. Understanding, i.e., explicit definition of these factors, would allow for constant observation of the behavioral trends and for organizing the activity in a way conducive for influencing the favorable change of these factors. In addition, the presence of the key performance indicators (KPI) system enables one to check the significance of any activity (i.e., any processes within a company) against these factors. The more significant the process, the more important is any knowledge regarding the ways of its realization.

It would be more difficult to group the results for each pattern (professional situation). This could be accomplished only through putting all the values onto the same scale. We suggest building radar charts, also called spider charts, of the type shown below (Figure 1.)

The quality of process realization also should be monitored. Therefore, for the goals set (at least, for the lower levels) the measurable indicators should be identified, which could determine the degree of goal accomplishment.

Building the «goal tree and selection of the critical management factors» brings a structure into the crucial level of the governance system of the professional and intellectual potential: the level at which the shift from «strategy to action» takes place. This model permits to connect the "strategic» and "operational» management levels and to form the correct strategic focus. On the one hand, the KPI of the goal tree are related to the processes (which ensure the achievement of these goals), on the other hand, they are related to the measurable indicators that can determine the degree of goal achievement.

Based upon the logical indices and empirical measurements, we developed our own analytical indices professional satisfaction, significance, communicativeness, motivation. We calculated the analytical indices for various respondent groups and then identified types according to this criterion as well as determined the composite index for the total aggregate.

Figure 1: Visualizing the Situations of Governing the Professional and Intellectual Potential at the Corporate Level

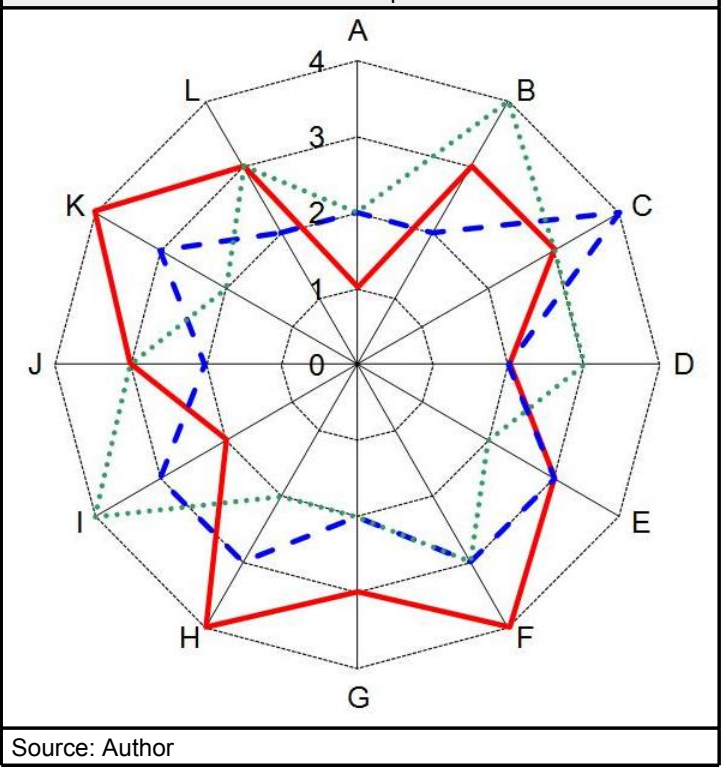

\section{REFERENCES}

1. Ahbel-Rappe, Sara, and Rachana Kamtekar (eds.), 2005, A Companion to Socrates, Oxford: Blackwell Publishers.

2. Henry, J. ,2002, Knowledge is Power. How Magic, the Government and an Apocalyptic Vision inspired Francis Bacon to create Modern Science, Cambridge.

3. Comte, August, 1853, The Positive Philosophy of Auguste Comte, freely translated and condensed, trans. Harriet Martineau, London: J. Chapman. Abridged from Cours de philosophie positive (Paris: Bachelier, 1830-42), 6 vols.

4. Spencer, Herbert [1873], The Study of Sociology, Ann Arbor: University of Michigan Press, 1969.

5. Durkheim, Emile, 1895, The Rules of Sociological Method, trans. W. D. Halls, New York: Free Press, 1982.

6. Weber, Max. 1968. Economy and Society, ed. Guenther Roth and Claus Wittich, Berkeley: University of California Press. 
CORPORATE KNOWLEDGE MANAGEMENT: INTERDISCIPLINARY APPROACH

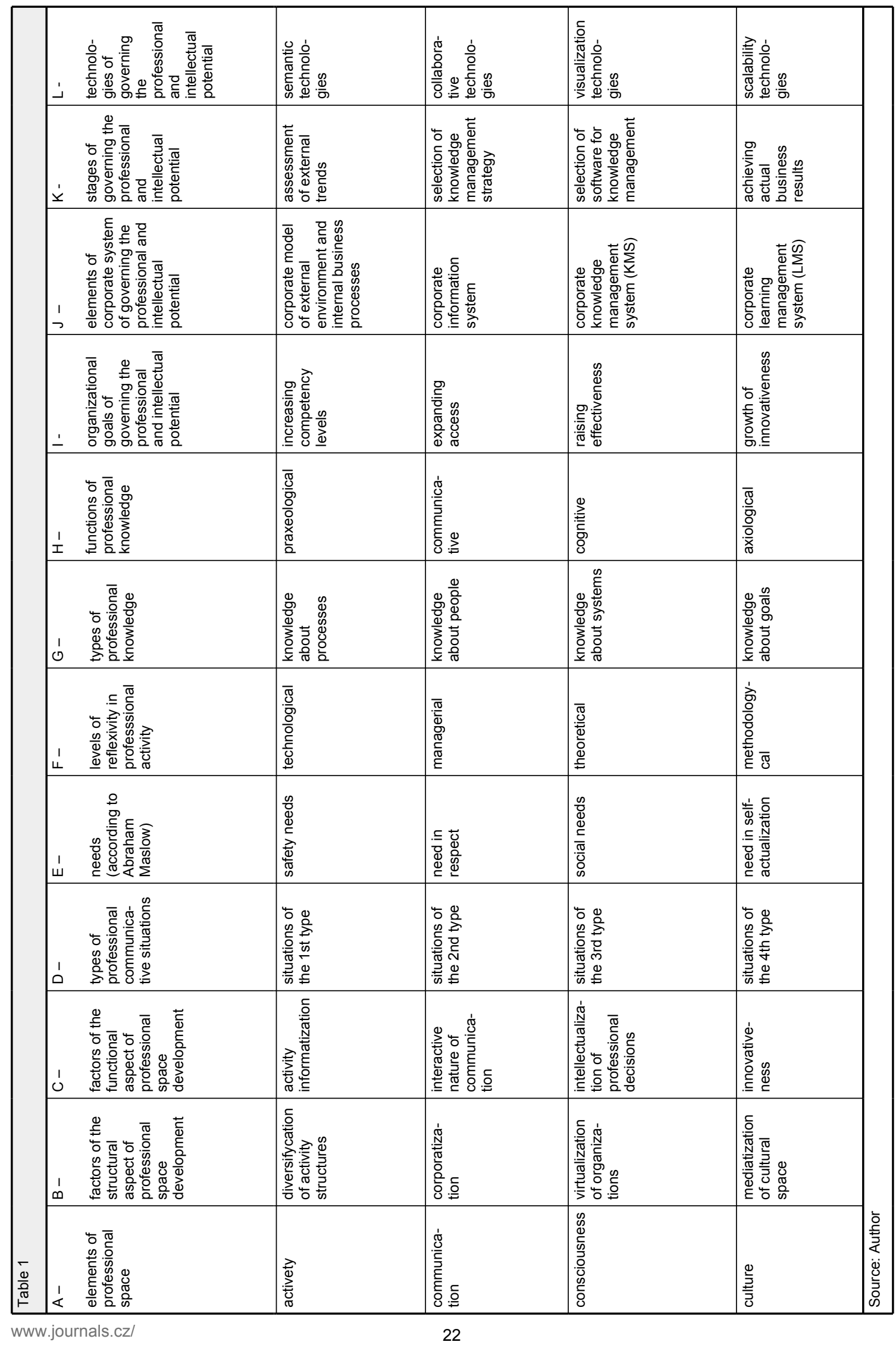


7. Parsons, Talcott, and Edward Shils, eds. 1951. Toward a general theory of action. New York: Harper \& Row.

8. Mannheim, Karl (1929/1936) Ideologie und Utopie. Bonn: F. Choen. Trans. by L. Wirth \& E. Shilds as Ideology and Utopia. New York, NY: Harcourt, Brace \& World.

9. McLuhan, Marshall (1964), Understanding Media: The Extensions of Man (New York: McGraw Hill).

10. High Tech/High Touch: Technology and Our Accelerated Search for Meaning by John Naisbitt (2001)

11. Megatrends 2010: The Rise of Conscious Capitalism by Patricia Aburdene (2005)

12. Toffler Alvin (1984) Future Shock (New York: Bantam)

13. Castells, Manuel (1996), The Rise of Network Society (Oxford, UK: Blackwell).

14. Knorr-Cetina, Karin. 1981. The Manufacture of Knowledge. Oxford: Pergamon Press

15. Latour, Bruno and Steven Woolgar. 1986. Laboratory Life: The Construction of Scientific Facts. 2d ed. Princeton, NJ: Princeton University Press.

16. Brooking, Annie, 1998. Corporate Memory: Strategies For Knowledge Management. Int. Thomson Business Press;

17. Edvinsson L., Malone M.S. Intellectual Capital. Realizing Your Company's True Value by Finding Its Hidden Roots, New York: HarperBusiness, 1997

18. Bourdieu, Pierre. Language and symbolic power. Cambridge: Polity Press, 1991.

19. Intangibles: Management, Measurement, and Reporting: by Baruch Lev, Washington, DC, Brookings Institution Press, 2001

20. The Knowledge Organisation Introduction, Celemi 1994; http://www.sveiby.com/Portals/0/articles/IntellectualCapital.html

21. Ikujiro Nonaka, Hiro Takeuchi. The Knowledge-creating Company: How Japanese Companies Create the Dynamics of Innovation. Oxford University Press Inc, USA (1995)

22. Kapterev A. I. Governing Professional and Intellectual Potential of a Modern Organization [Upravlenie professional'no-intellektual'nim potentsialom sovremennoi organizatsii] Monograph.- M.- 2004.- 302 pp.- Orig.ru. 